УДК 581.143.6:633.15

\author{
К. В. Деркач*, О. С. Абраімова*, Т. М. Сатарова*,** \\ *Iнститут сільського господарства степової зони НААН Украӥни \\ **Украӥнський державний хіміко-технологічний університет
}

\title{
КАЛУСОГЕННИЙ ПОТЕНЦАЛ ЛІНІЙ КУКУРУДЗИ ГРУПИ ЛАНКАСТЕР В УМОВАХ IN VITRO
}

\begin{abstract}
Оцінено лінії кукурудзи групи Ланкастер щодо реакції їх незрілих зародків на культивування in vitro. Здатність до калусогенезу зумовлена генотипом і залежить від наявності в родоводі лінії підплазми Oh43. Встановлено, що частота морфогенного калусогенезу для чутливих до культивування ліній групи Ланкастер складає 30-84 \%. Визначено лінії, перспективні для використання у клітинній і генетичній інженерії кукурудзи за здатністю до утворення морфогенних калусів.
\end{abstract}

\author{
Е. В. Деркач*, О. Е. Абраимова*, Т. Н. Сатарова* ** \\ *Институт сельского хозяйства степной зоны НААН Украины \\ **Украинский государственный химико-технологический университет

\section{КАЛУСОГЕННЫЙ ПОТЕНЦИАЛ ЛИНИЙ КУКУРУЗЫ ГРУППЫ ЛАНКАСТЕР В УСЛОВИЯХ IN VITRO}

Оценены линии кукурузы группы Ланкастер в отношении реакции их незрелых зародышей на культивирование in vitro. Способность к каллусогенезу обусловлена генотипом и зависит от наличия в родословной линии подплазмы Oh43. Установлено, что частота морфогенного каллусогенеза для чувствительных к культивированию линий группы Ланкастер находится на уровне 30-84 \%. Выявлены линии, перспективные для использования в клеточной и генетической инженерии кукурузы по способности к образованию морфогенных каллусов.

$$
\begin{aligned}
& \text { K. V. Derkach*, O. E. Abraimova*, T. M. Satarova*,** } \\
& \text { *Institute of Steppe Zone Agriculture, NAAS of Ukraine } \\
& \text { **Ukrainian State University of Chemistry and Technology }
\end{aligned}
$$

\section{CALLUSOGENIC POTENTIAL OF MAIZE LINES OF LANCASTER GROUP IN VITRO}

The estimation of maize inbred lines of the Lancaster group for immature embryos response to cultivation in vitro was made. It was noted that ability to callusogenesis was genotypically determined and depended on the presence of the subplasm Oh43 lineage. It was established that frequency of morphogenic callusogenesis in sensitive to cultivation Lancaster group lines was at the level of 30-84\%. Promising maize inbreds cell and genetic engineering by an ability to produce morphogenic calli were identified.

\section{Вступ}

На сучасному етапі перед селекцією кукурудзи постає питання створення нових генотипів, які володіють високою врожайністю, посухостійкістю, стійкістю до засолення грунтів, хвороб, шкідників тощо. Біотехнологічні методи, зокрема застосування культури тканин, здатні сприяти розширенню генетичного різноманіття вихідного се- 
лекційного матеріалу. Морфогенні калуси кукурудзи різних типів, отримані в процесі культивування незрілих зародків, широко використовуються у клітинній і генетичній інженерії, оскільки здатні до швидкої регенерації рослин і продукування сомаклональних варіантів $[1 ; 7 ; 8]$. Їх поділяють на два основні типи: калуси типу I, або компактні, та калуси типу II, або пухкі [6]. Калус типу I росте повільно, швидко переходить до регенерації і не здатний до тривалого підтримання в культурі. Калус типу II відрізняється швидким ростом, здатний до тривалого підтримання при регулярному субкультивуванні. При зниженні концентрації ауксинів калус типу II також переходить до регенерації. Для конкретних біотехнологічних маніпуляцій важливе визначення генотипів кукурудзи, здатних до утворення морфогенних калусів певного типу. У зв'язку з цим актуальною є характеристика калусогенного потенціалу ліній кукурудзи, які являють собою перспективний вихідний селекційний матеріал.

Сучасний селекційний генофонд кукурудзи - результат багатьох циклів схрещувань і доборів серед декількох вихідних сортів. Генотипи кукурудзи, які походять від одного вихідного сорту, об’єднують під назвою «зародкова плазма» [5]. Широко відомі, у тому числі і в Україні, зародкові плазми Ланкастер, Айодент, Рейд, Міндзенпуста, BSSS та інші.

Зародкова плазма Ланкастер має значні потенційні переваги для створення на іï основі нового вихідного й елітного селекційного матеріалу для вирощування в Україні [3; 4]. Лінії плазми Ланкастер за родоводом поділяють на підплазми Oh43, Mo17, Mo17/Oh43, Mo17/O92, Мo17/F2, Мо17/Міндзенпуста та інші. Проте результати цілеспрямованого вивчення калусогенного потенціалу ліній групи Ланкастер відсутні.

Мета нашого дослідження - оцінити калусогенний потенціал перспективних для селекційних досліджень ліній кукурудзи зародкової плазми Ланкастер в умовах in vitro.

\section{Матеріал і методи досліджень}

Матеріалом дослідження слугували 10 перспективних у селекційному відношенні ліній кукурудзи зародкової плазми Ланкастер, а саме лінії ДК267, ДК212, ДК6080 та ДК420-1, які є представниками підплазми Oh43, лінії ДК633/266 та ДК298, які належать до підплазми Mo17/Oh43, лінія ДК633 (підплазма Мo17), лінія ДК3070 (підплазма Мо17/O92), лінія ДК236 (підплазма Мo17/F2) і лінія ДК633/325 (підплазма Мo17/Міндзенпуста). За стандарт використано широко відому у біотехнологічних дослідженнях лінію Chi31 (екзотична зародка плазма, підплазма Chi31) [9].

Донорні рослини вирощували у польових умовах за загальноприйнятою методикою польового досліду. Ізольовані незрілі зародки довжиною 1-1,5 мм на 10-12-ту добу після запилення експлантували на живильне середовище $\mathrm{N}_{6}$ iз додаванням 100 мг/л гідролізату казеїну, 100 мг/л мезоінозиту, 690 мг/л $L$-проліну, 30 г/л сахарози, 10 мг/л нітрату срібла, 1 мг/л 2,4-дихлорфеноксіоцтової кислоти та 0,1 мг/л абсцизової кислоти. Культивування проводили у темряві за температури $+25 \ldots+27^{\circ} \mathrm{C}$.

Результати культивування реєстрували на 30 -ту добу від експлантації зародків. Загальну частоту калусогенезу розраховували як процентне відношення кількості зародків, які сформували калус, до загальної кількості культивованих зародків. Частоти утворення морфогенних калусів, калусів типів I і II розраховували як процентне відношення зародків із певним типом реакції до загальної кількості культивованих зародків. Частоту спонтанної регенерації розраховували як процентне відношення кількості зародків, які утворили пагони на індуктивному живильному середовищі, до загальної кількості культивованих зародків. Статистичну обробку даних проводили 
згідно з [2]. Дані в таблицях представлені у вигляді $\bar{x} \pm m t_{0.05}$, де $\bar{x}$ - середнє арифметичне значення показника, $m$ - похибка середнього арифметичного, $t_{0,05}$ - критерій Стьюдента за рівня значущості 0,05 .

\section{Результати та їх обговорення}

Реакцією у вигляді калусогенезу характеризувалися лінії, які належали до підплазм Oh43 та Mo17/Oh43 (табл. 1). Тобто присутність у родоводі лінії підплазми Oh43 зумовлювала іiі калусогенну здатність. Загальний калусогенез чутливих ліній знаходився на рівні стандарту або перевершував його. Нечутливими до культивування виявилися лінії, у родоводі яких за відсутності підплазми Oh43 була присутня підплазма Mo17.

Реакція ліній кукурудзи плазми Ланкастер на культивування in vitro

Таблиия 1

\begin{tabular}{|c|c|c|c|}
\hline Лінія & Підплазма & $\begin{array}{c}\text { Кількість культивованих } \\
\text { зародків, шт. }\end{array}$ & $\begin{array}{l}\text { Загальна частота } \\
\text { калусогенезу, \% }\end{array}$ \\
\hline ДК267 & Oh43 & 452 & $87,61 \pm 3,10$ \\
\hline ДК212 & Oh43 & 268 & $91,04 \pm 3,49$ \\
\hline ДК6080 & Oh43 & 186 & $98,92 \pm 1,52$ \\
\hline ДК420-1 & Oh43 & 199 & $92,46 \pm 3,75$ \\
\hline ДК633/266 & Mo17/ Oh43 & 383 & $98,96 \pm 1,04$ \\
\hline ДК298 & Mo17/Oh43 & 372 & $96,77 \pm 0,94$ \\
\hline ДК633 & Mo17 & 474 & 0 \\
\hline ДК 3070 & Mo17/ O92 & 193 & 0 \\
\hline ДК236 & $\mathrm{Mo17/F2}$ & 445 & 0 \\
\hline ДК633/325 & Мо17/ Міндзенпуста & 534 & 0 \\
\hline Chi31 & екзотична плазма, підплазма Chi31 & 473 & $91,33 \pm 1,30$ \\
\hline
\end{tabular}

Для чутливих ліній у таблиці 2 наведено частоти утворення морфогенних калусів, калусів типів I і II та калусів, які виявили здатність до спонтанної регенерації. Усі проаналізовані генотипи здатні до утворення морфогенних калусів і калусів типу II. Калуси типу I утворювали всі генотипи, крім лінії ДК6080. Спонтанну регенерацію на 30-ту добу культивування зафіксовано лише у лінії ДК633/266 на рівні 15,4 \%. Частота утворення морфогенних калусів коливалася у межах 30,2-84,6 \%.

Табличя 2

Характеристика калусогенезу ліній кукурудзи

\begin{tabular}{|c|c|c|c|c|}
\hline Лінія & $\begin{array}{l}\text { Кількість культиво- } \\
\text { ваних зародків, шт. }\end{array}$ & $\begin{array}{c}\text { Частота утворення } \\
\text { морфогенних калусів, \% }\end{array}$ & $\begin{array}{l}\text { Частота утворення } \\
\text { калусів типу I, \% }\end{array}$ & $\begin{array}{l}\text { Частота утворення } \\
\text { калусів типу II, \% } \\
\end{array}$ \\
\hline \multicolumn{5}{|c|}{ Плазма Ланкастер, підплазма Oh43 } \\
\hline ДК267 & 452 & \begin{tabular}{|l|l|}
$71,46 \pm 4,25$ \\
\end{tabular} & $67,92 \pm 4,40$ & $3,54 \pm 1,74$ \\
\hline ДК212 & 268 & $40,67 \pm 6,01$ & $13,81 \pm 4,22$ & $26,87 \pm 5,43$ \\
\hline ДК6080 & 186 & $37,63 \pm 7,12$ & 0 & $37,63 \pm 7,12$ \\
\hline ДК420-1 & 199 & $30,15 \pm 6,52$ & $2,51 \pm 2,22$ & $27,64 \pm 6,36$ \\
\hline \multicolumn{2}{|c|}{ Середнє } & \begin{tabular}{|l|l}
$44,98 \pm 6,07$ \\
\end{tabular} & $21,06 \pm 4,32$ & $23,92 \pm 5,56$ \\
\hline \multicolumn{5}{|c|}{ Плазма Ланкастер, підплазма Mo17/ Oh43 } \\
\hline ДК633/266 & 383 & \begin{tabular}{|l|l}
$84,60 \pm 3,69$ \\
\end{tabular} & $5,48 \pm 2,33$ & $79,11 \pm 4,16$ \\
\hline ДК298 & 372 & $78,49 \pm 4,27$ & $34,68 \pm 4,94$ & $43,82 \pm 5,15$ \\
\hline \multicolumn{2}{|c|}{ Середнє } & \begin{tabular}{|l|}
$81,55 \pm 5,64$ \\
\end{tabular} & $20,08 \pm 5,46$ & $61,47 \pm 6,62$ \\
\hline \multicolumn{5}{|c|}{ Екзотична плазма, підплазма Chi31 } \\
\hline Chi31 & 473 & \begin{tabular}{|l|}
$59,20 \pm 4,52$ \\
\end{tabular} & $19,66 \pm 3,66$ & $39,53 \pm 4,50$ \\
\hline
\end{tabular}


Високий рівень даного показника спостерігався у ДК267, ДК633/266, ДК298 та Chi31, низький - у ДК212, ДК6080 та ДК420-1. Загалом, частота утворення морфогенних калусів у проаналізованих ліній підплазми Mo17/Oh43 була вищою, ніж у ліній підплазми Oh43. Частота утворення калусів типу I коливалася в діапазоні 0-67,9\%.

Найвищим цей показник був у ДК267. Найнижча частота утворення калусів типу I відмічена у ДК420-1 і ДК633/266, зовсім відсутня здатність до калусоутворення цього типу у ДК6080. Частота утворення калусів типу II коливалася у діапазоні 3,5-79,1 \%. Найвищим цей показник був у ДК633/266, найнижчим - у ДК267.

У кожного генотипу, крім лінії ДК298, переважав той чи інший тип калусу (див. табл. 2). Більшість ліній підплазми Oh43 переважно формувала калус типу II. Серед досліджених представників підплазми Мo17/Oh43 лінія ДК633/266 утворила переважно калуси типу II, а ДК298 - майже порівну калуси обох типів. Порівняння наведених у таблиці 2 показників у ліній групи Ланкастер і лінії Chi31 показує, що лінії ДК267, ДК633/266, ДК298 перевищують стандарт за частотою утворення морфогенних калусів, лінії ДК267, ДК298 - за частотою утворення калусів типу I, лінія ДК633/266 калусів типу II.

Таким чином, для підплазми Oh43 базовою для отримання калусів типу I може слугувати лінія ДК267, калусів типу II - лінії ДК420-1 та ДК6080, обох типів одночасно - лінія ДК212. Для підплазми Mo17/Oh43 базовими для отримання калусів типу I, типу II та обох типів одночасно можуть бути обрані, відповідно, лінії ДК298, ДК633/266 та ДК298.

Калуси кожної лінії мали свої характерні особливості. Нижче представлено зовнішній вигляд на 30-ту добу культивування та описи калусів досліджених ліній, які можуть бути використані для їх ідентифікації та прогнозу морфогенетичного потенціалу.

Лінія ДК267 утворює типовий калус типу I світло-жовтого кольору, на ньому чітко вирізняються ембріоїдні структури (рис. 1.1). Окремі калуси цієї лінії розрізняються за розмірами, що може бути пов'язано з місцем розташування зародків на качані. Лінія ДК212 (рис. 1.2) утворює порівняно небагато морфогенних калусів від світлокоричневого до світло-жовтого кольору, ембріоїдні структури не спостерігаються, численні калуси швидко переходять до коренеутворення. Лінія ДК6080 (рис. 1.3) утворює великі пухкі, світло-жовті калуси типу II, проте ембріоїдні структури чітко не вирізняються. Калуси лінії ДК420-1 (рис. 1.4) мають середні розміри порівняно з калусами інших ліній. Калуси типу II цієї лінії пухкі, світло-жовті, спостерігається невелика кількість ембріоїдних структур, деякі калуси виявляють ризогенність.

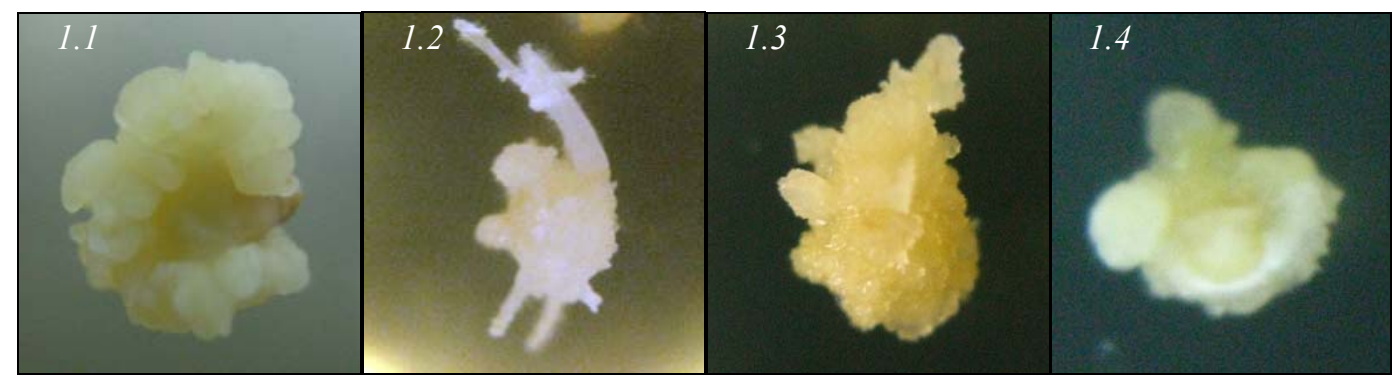

Рис. 1. Зовнішній вигляд калусів ліній кукурудзи підплазми Оh43 плазми Ланкастер на 30-ту добу культивування: 1.1 - ДК267, 1.2 - ДК212, 1.3 - ДК6080, 1.4 - ДК420-1 
Калуси лінії ДК633/266 (рис. 2.1) великі, світло-жовтого кольору, утворюються як під щитком, так і на ньому. У цієї лінії переважає калус типу II, хоча відмічається й калус типу I із добре помітними ембріоїдними структурами, деякі калуси у зазначений період культивування спонтанно переходять до регенерації. Калуси лінії ДК298 (рис. 2.2) середнього розміру порівняно 3 калусами інших ліній мають світло-жовте забарвлення, відмічено ембріоїдні структури. Лінія Сhi31 (рис. 2.3) переважно утворювала світло-жовті, великі калуси типу II та окремі калуси типу I середнього розміру.

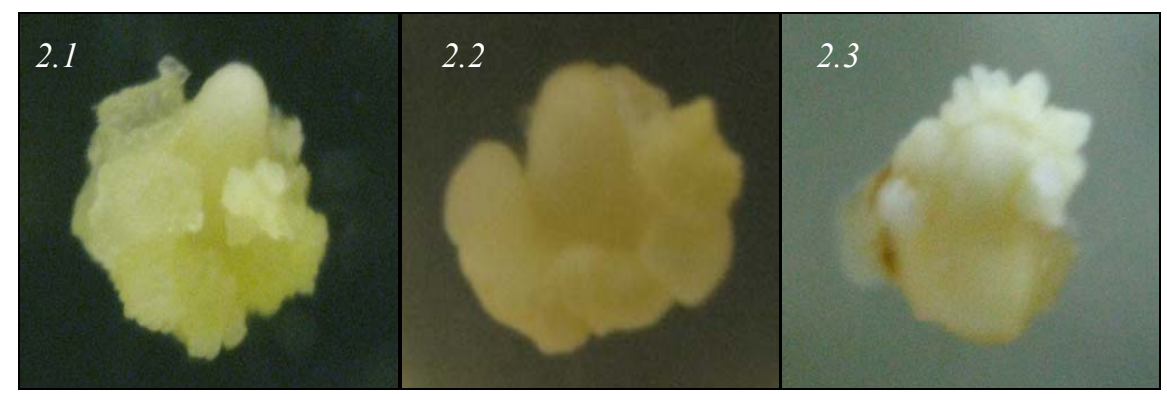

Рис. 2. Зовнішній вигляд калусів ліній кукурудзи підплазми Мо17/Оh43 плазми Ланкастер і лінії підплазми Chi31 екзотичної плазми на 30-ту добу культивування: 2.1 - ДК633/266, 2.2 - ДК298, 2.3 - Chi31

На 30-ту добу культивування зародки лінії ДК633 (рис. 3.1) мали дрібні, набухлі, світло-жовті щитки, на яких з'являлися ледь помітні меристематичні зони. У лінії ДК3070 (рис. 3.2) щитки великі, набухлі, світло-жовтого та світло-коричневого кольору, деякі зародки виглядали обводненими. Лінії ДК236 (рис. 3.3) і ДК633/325 (рис. 3.4) характеризуються набухлими світло-жовтими щитками, на яких спостерігаються білі, ледь помітні зони меристематичної активності. Лінії ДК633, ДК3070, ДК236 та ДК633/325 типових калусів не утворюють.

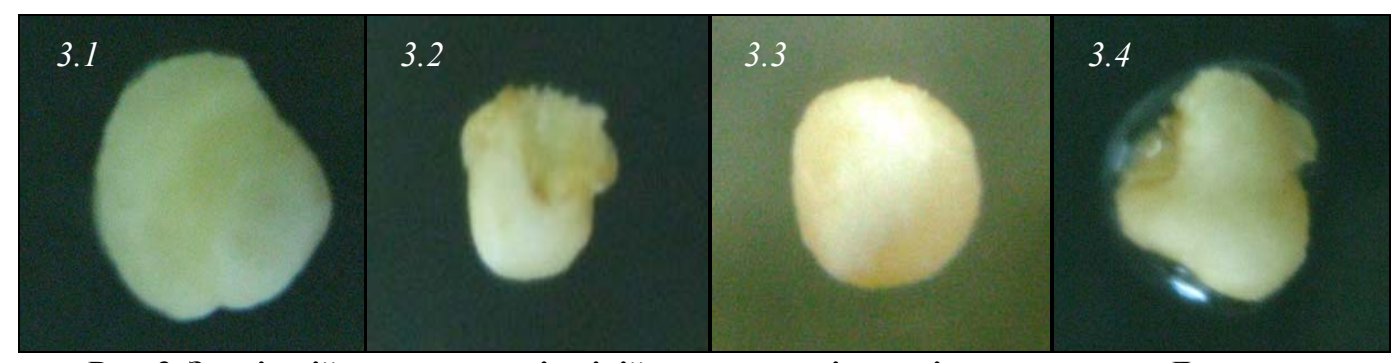

Рис. 3. Зовнішній вигляд калусів ліній кукурудзи різних підплазм плазми Ланкастер на 30-ту добу культивування: 3.1 - ДК633, 3.2 - ДК3070, 3.3 - ДК236, 3.4 - ДК633/325

Для ліній ДК6080, ДК3070 і ДК236 характерне проростання зародкових вісей упродовж перших двох тижнів культивування.

\section{Висновки}

Чутливість кукурудзи до культивування в умовах in vitro залежить від генотипічних особливостей ліній. Зародкова плазма Ланкастер характеризується здатністю до морфогенного калусогенезу на рівні 30-84 \%. Присутність у родоводі лінії підплазми Oh43 сприяє калусогенезу. Визначено лінії плазми Ланкастер із високою здатністю до морфогенного калусогенезу різних типів, які можуть слугувати базовими для регенерації рослин, отримання сомаклонів та ефективної генетичної трансформації. Для підплазми Oh43 базовою для отримання калусів типу I рекомендується лінія 
ДК267, калусів типу II - лінії ДК420-1 і ДК6080, обох типів одночасно - лінія ДК212. Для підплазми Mo17/Oh43 базовими для продукування калусів типів I, II та обох типів одночасно можуть бути, відповідно, обрані лінії ДК 298, ДК633/266 і ДК298.

\section{Бібліографічні посилання}

1. Калусогенез у ліній кукурудзи на фоні ауксинового навантаження / Т. М. Сатарова, Г. Р. Піралов, Н. А. Боденко, О. Є. Абраімова // Бюлетень Інституту зернового господарства. - 2010. № 38. - С. 55-60.

2. Лакин Г. Ф. Биометрия. - М. : Высш. шк., 1990. - 352 с.

3. Нові ранньостиглі та середньоранні самозапилені лінії плазми Ланкастер / Є. І. Бєліков, А. В. Алдошин, Т. Г. Купріченкова та ін. // Бюлетень Інституту зернового господарства. 2005. - № 23-24. - С. 21-24.

4. Олешко О. Г. Ідентифікація самозапильних ліній кукурудзи, створених на базі різних генетичних плазм. Автореф. дис. ... канд. с.-г. наук: 06.01.05. - Д., 2007. - 16 с.

5. Селекционная оценка элитных самоопыленных линий кукурузы из основных гетерозисных групп зародышевой плазмы / В. М. Соколов, Б. Ф. Вареник, А. С. Пилюгин и др. // Генетика, селекция и технология возделывания кукурузы. - 1999. - С. 92-96.

6. Armstrong C. L. Establishment and maintenance of friable, embryogenic maize callus and the involvement of $L$-proline / C. L. Armstrong, C. E. Green // Planta. - 1985. - Vol. 164. - P. 207-214.

7. O'Kennedy M. M. Biolistic-mediated transformation protocols for maize and pearl millet using precultured immature zygotic embryos and embryogenic tissue / M. M. O'Kennedy, H. C. Stark, N. Dube // Methods in Molecular Biology. - 2011. - Vol. 710, part 5. - P. 343-354.

8. Ombori O. Somatic embryogenesis and plant regeneration from immature embryos of tropical maize (Zea mays L.) inbred lines / O. Ombori, N. M. Gitonga, J. Mschuka // Biotechnology. - 2008. - N 7 (2). P. 224-232.

9. Somaclonal variation in the $R_{3}$-generation of a maize inbred line / J. Lazanyi, F. J. Novak, H. Brunner et al. // Acta Agronomica Hungarica. - 1990. - № 39 (1-2). - P. 101-108.

Надійшла до редколегії 10.01.2011 